\title{
Archaeological Discoveries on Schnidejoch and at Other Ice Sites in the European Alps
}

\author{
ALBERT HAFNER ${ }^{1}$
}

\author{
(Received 28 February 2011; accepted in revised form 19 December 2011)
}

\begin{abstract}
Only a few sites in the Alps have produced archaeological finds from melting ice. To date, prehistoric finds from four sites dating from the Neolithic period, the Bronze Age, and the Iron Age have been recovered from small ice patches (Schnidejoch, Lötschenpass, Tisenjoch, and Gemsbichl/Rieserferner). Glaciers, on the other hand, have yielded historic finds and frozen human remains that are not more than a few hundred years old (three glacier mummies from the 16th to the 19th century and military finds from World Wars I and II). Between 2003 and 2010, numerous archaeological finds were recovered from a melting ice patch on the Schnidejoch in the Bernese Alps (Cantons of Berne and Valais, Switzerland). These finds date from the Neolithic period, the Early Bronze Age, the Iron Age, Roman times, and the Middle Ages, spanning a period of 6000 years. The Schnidejoch, at an altitude of $2756 \mathrm{~m}$ asl, is a pass in the Wildhorn region of the western Bernese Alps. It has yielded some of the earliest evidence of Neolithic human activity at high altitude in the Alps. The abundant assemblage of finds contains a number of unique artifacts, mainly from organic materials like leather, wood, bark, and fibers. The site clearly proves access to high-mountain areas as early as the 5th millennium BC, and the chronological distribution of the finds indicates that the Schnidejoch pass was used mainly during periods when glaciers were retreating.
\end{abstract}

Key words: ice patch archaeology, Alps, Switzerland, Neolithic, Bronze Age, Iron Age, Roman Period, Medieval Period, bow equipment, climate history, alpine pass

RÉSUMÉ. Dans les Alpes, la glace en fusion a donné lieu à des découvertes archéologiques à seulement quelques emplacements. Jusqu'à maintenant, des découvertes préhistoriques en provenance de quatre sites remontant à la période néolithique, à l'âge du bronze et à l'âge du fer ont été faites dans de petits névés (Schnidejoch, Lötschenpass, Tisenjoch et Gemsbichl-Rieserferner). Par contre, les glaciers ont permis de faire des trouvailles historiques et de découvrir des restes humains qui ne datent pas de plus de quelques centaines d'années (soit trois momies de glaciers allant du XVI ${ }^{\mathrm{e}}$ au XIX ${ }^{\mathrm{e}}$ siècles et des découvertes militaires de la Première Guerre mondiale ainsi que de la Seconde Guerre mondiale). Entre 2003 et 2010, de nombreuses découvertes archéologiques ont été effectuées dans un névé en fusion du Schnidejoch, dans les Alpes bernoises (cantons de Berne et de Valais, en Suisse). Ces découvertes datent de la période néolithique, du début de l'âge du bronze, de l'âge du fer, de l'époque romaine et du Moyen-Âge, ce qui s'échelonne sur 6000 années. Le Schnidejoch, se trouvant à une altitude de $2756 \mathrm{~m}$, est un col de la région Wildhorn, dans l'ouest des Alpes bernoises. Cet endroit a permis de découvrir les plus anciennes preuves d'activité humaine de la période néolithique en haute altitude dans les Alpes. L'abondant assemblage de découvertes comprend un certain nombre d'artefacts uniques principalement composés de matériaux organiques comme le cuir, le bois, l'écorce et les fibres. Ce site prouve nettement que dès le cinquième millénaire av. J.-C., l'être humain avait accès aux régions en haute montagne. Par ailleurs, la répartition chronologique des découvertes indique que le col du Schnidejoch était principalement utilisé en périodes de recul des glaciers.

Mots clés : archéologie des névés, Alpes, Suisse, néolithique, âge du bronze, âge du fer, période romaine, période médiévale, équipement d'arc, histoire du climat, col alpin

Traduit pour la revue Arctic par Nicole Giguère.

\section{INTRODUCTION}

Archaeological finds retrieved from ice are a rather recent phenomenon, perhaps because ice patches are in locations that are not very easily accessed: polar and subpolar regions or nival and subnival areas of high mountain ranges. Outside the Alps, ice patch finds are known from Scandinavia (Farbregd, 1972, 2009; Astveit, 2007; Finstad and Pilø, 2010) and North America (Farnell et al., 2004; Hare et al., 2004; Dixon et al., 2005; VanderHoek et al., 2007a, b; Andrews et al., 2009; Lee, 2010). Schär et al. (2004) point out that instrumental observation and reconstructions of global and hemispheric temperature evolution reveal pronounced warming during the last 150 years, which led to glaciers retreating, ice patches becoming smaller, and permafrost soils thawing to a deeper extent. This process has significantly accelerated in recent years. When glaciers and ice patches melt, the terrain uncovered has usually not been

\footnotetext{
${ }^{1}$ Archäologischer Dienst des Kantons Bern, Postfach 5233, CH-3001 Bern, Switzerland; present address: Institute of Archaeological Science, Department of Prehistory, University of Bern, CH-3012 Bern, Switzerland; albert.hafner@erz.be.ch

(C) The Arctic Institute of North America
} 
exposed for a long time. Archaeological artifacts that have been trapped in the ice for hundreds and sometimes thousands of years come to light once again.

When a Neolithic ice mummy dating around 3300-3100 BC was discovered in 1991 in the Ötztal Alps (Austria/ Italy), it constituted the first ever recognized Neolithic ice-patch find in the Alps (Höpfel et al., 1992; Spindler et al., 1995, 1996; Bortenschlager and Oeggl, 2000; Egg and Spindler, 2009). The site was located at an altitude of $3210 \mathrm{~m}$ on the Tisenjoch, a crossing from the Ötztal Valley in the north to the Schnalstal Valley in the south. Until this discovery, researchers had generally assumed that alpine regions above the tree line and above $2000 \mathrm{~m}$ had not been frequented at all during the Neolithic period (5500-2200 BC). This opinion seemed to be confirmed by the nearly complete absence of finds dating from the period of the earliest farming communities. It was presumed that the Neolithic societies had no interest in regions with a low farming potential (Wyss, 1991). The earliest groups that were believed to have operated an early pasture economy and to have used the alpine zone were the Bronze Age populations (2200-800 BC). Archaeological evidence in the remains of high-altitude settlements and individual finds of bronze artifacts had already come to light at the beginning of the 20th century (Wyss, 1971). Human remains found on glaciers had also been known for a long time. In most cases these were modern-day mountaineers who had died as a result of accidents and were therefore not archaeological finds in the strict sense (Meyer, 1992). The novelty and surprising feature of the Tisenjoch ice mummy find was actually that it was lying in stagnant ice in a hollow surrounded by steep ridges (Egg and Spindler, 2009:39-45 and Figs. 7-9). The excellent preservation conditions that existed on the Tisenjoch were thus due to its special topographical features. That such ice-filled hollows are rare is illustrated by the fact that despite intensive searches in various regions of the Alps, only two new finds have come to light since 1991.

\section{ICE PATCH AND GLACIER SITES IN THE ALPS}

In the entire alpine region four sites are known to have yielded prehistoric finds from the ice (Fig. 1:1-4). Besides Tisenjoch and Schnidejoch, mentioned above, the prehistoric ice patch sites of Lötschenpass in the western Bernese Alps and Gemsbichl/Rieserferner in the Noric Alps can be cited. Historic finds from glaciers are known from Switzerland, Austria, and Italy. Of archaeological interest are three frozen human bodies that were embedded in the ice between the 16th and 19th centuries (Fig. 1:5-7). The scattered corpses and their dispersed equipment were found on the lowest parts of alpine glaciers. In contrast to ice patches, alpine glaciers move down the valley at an average speed of 10 to $30 \mathrm{~m}$ per year. This means that persons or objects that fall into crevasses are transported approximately 1 to $3 \mathrm{~km}$ over a period of 100 years. For reasons of glacier mechanics, archaeological finds more than a few hundred years old cannot be expected. The latest archaeological remains stem from alpine military actions (Fig. 1.8-11). The sites include World War I battlefields in the former Austro-Italian border zones, from the so-called Guerra Bianca (White War) of 1915-18, and wrecks of two aircraft that crashed on glaciers during and shortly after World War II.

\section{Lötschenpass}

Between 1934 and 1944, several bows, bow fragments, medieval crossbow bolts, Roman coins, and other items were discovered on the Lötschenpass at $2690 \mathrm{~m}$ above sea level (asl) in the Bernese Alps of Switzerland (Bellwald, 1992; Meyer, 1992; Hafner, 2008). It was not until 1989 that the bows were rediscovered in the former workshop of the finder. Radiocarbon dating revealed that they date from the end of the Neolithic period and the Early Bronze Age (2400-1800 BC).

\section{Gemsbichl/Rieserferner}

In 1992 and 1994, several textiles and leather fragments were found on an ice patch near Gemsbichel/Rieserferner (2841 $\mathrm{m}$ asl), a pass in the South Tyrol (Italy). The findings consist of one pair of "socks," two pairs of woolen leggings, strips and cords of wool, and two sewn leather fragments, probably parts of shoes. The objects are probably parts of personal equipment that were lost in the same event. Radiocarbon dating of one item reveals that the object stems from the Iron Age, around 800-500 BC (dal Ri, 1996; Bazzanella et al., 2005).

\section{Theodul Glacier}

Between 1985 and 1990, the scattered skeletal remains of a man approximately 45 years old at the time of his death were found on the Theodul Glacier in the Pennine Alps south of Zermatt (Switzerland); a rapier, a dagger, and a pistol, as well as the remnants of clothing and shoes, were also found (Meyer, 1992). The site is located at an altitude of approximately $3000 \mathrm{~m}$ asl. Twelve coins were also found, with issue dates ranging from 1578 to 1588 , which means that the accident may have occurred at the end of the 16th century.

\section{Porchabella Glacier}

"Porchabella" was the name given to a woman aged between 20 and 30, who had probably been the victim of an accident in the 17th century and whose remains were found between 1988 and 1992 at the foot of the Piz Kesch in the Albula region. She had obviously met her death while trying to cross the Porchabella Glacier. The site is situated at an altitude of $2680 \mathrm{~m}$ asl. The remains included the skull, ribs, and fragments of the pelvis, hair, and body tissue. She had been wearing a woolen coat, a felt hat, a blouse, 


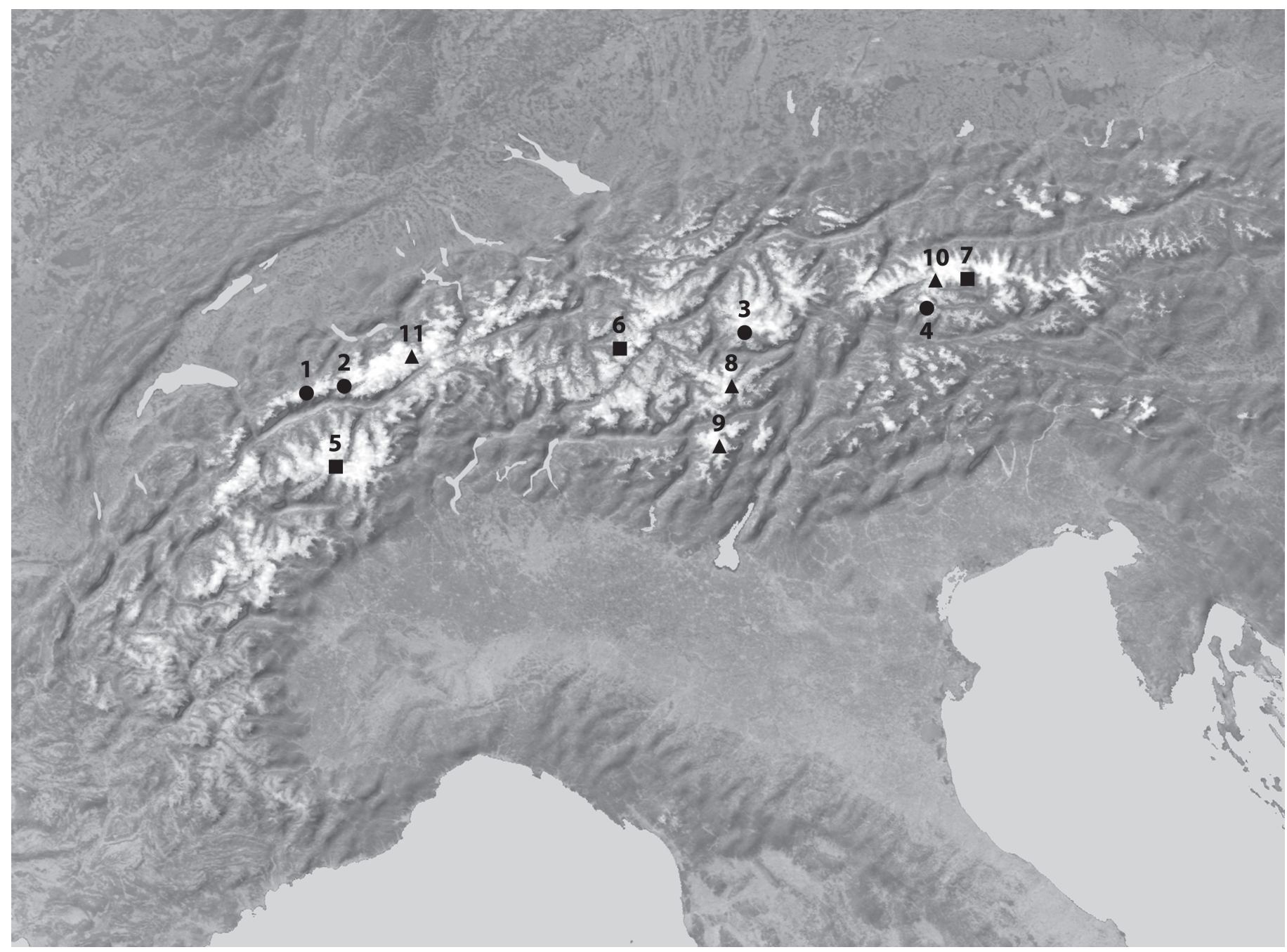

FIG. 1. Location of prehistoric ice patch and historic glacier sites in the European Alps, Switzerland, cited in the text. Prehistoric ice patch sites (dot): 1 Schnidejoch, 2 Lötschenpass, 3 Tisenjoch, 4 Gemsbichl/Rieserferner. Historic glacier sites, 17th to 19th century (square): 5 Theodul Glacier, 6 Porchabella Glacier 7, Gradetzkees. Battlefields of World War I or airplane wrecks of World War II (triangle): 8 Ortles region, 9 Adamello region, 10 Umbalkees, 11 Gauli Glacier.

and leather shoes. Various small finds-a bowl, a spoon, a comb, and rosary beads, all made of wood-were also recovered (Rageth, 1995).

\section{Gradetzkees}

The Gradetzkees is a glacier in the Granatspitz Mountains of Eastern Tyrol (Austria). In 1929 a glacier mummy melted out of the ice at about $2800 \mathrm{~m}$ asl. The head and other body extremities were missing, whereas parts of the clothing, buttons, hair, a knife, bullets, a rifle, and a pocketwatch were found nearby. Police investigations revealed that the body must be that of the poacher Norbert Mattersberger, who was lost in the area in 1829. However, because no autopsy was undertaken and the human remains were buried soon after the body was found, the identity of the person remains uncertain (Stadler, 2005).

\section{War Relics and Military Items}

From the 1990s on, archaeologists found high-alpine World War I fighting positions in the Ortles and Adamello regions of Italy covered by thick layers of ice, and discovered cantonments, checkpoints, weapons, and personal objects. Since 2004, several corpses of Austro-Hungarian soldiers have been found (Martinelli, 1996-2002; Rasper, 2011). Military items include wrecks of airplanes that crashed on glaciers during or shortly after World War II. In 2003, the remains of a German Junkers Ju 52 were found at about $2750 \mathrm{~m}$ asl on the Umbalkees, a glacier in the Hohe Tauern region of Eastern Tyrol. The plane had been forced to land in January 1941 (Von Schulz, 2003). In 1946, a Douglas Dakota C-53 from the United States Air Force crashed on the Gauli Glacier in the Bernese Alps. The wreck sank in the ice at about $3350 \mathrm{~m}$ asl. It is still in the glacier and will probably melt out in the next few years (Cornioley, 2006). 


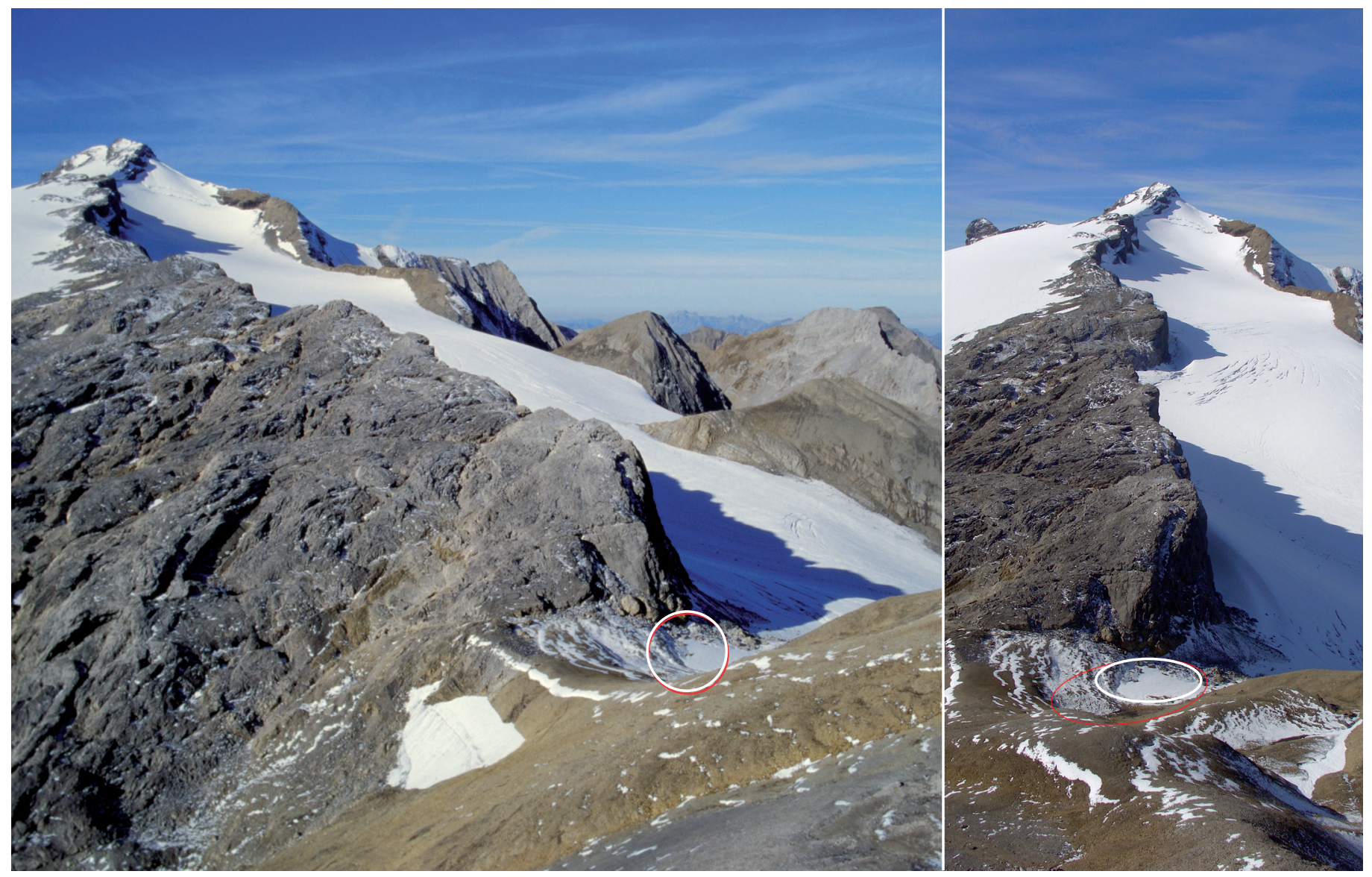

FIG. 2. Schnidejoch (Bernese Alps, Switzerland). View of the site at $2750 \mathrm{~m}$ asl which is situated in the foreground, marked by a oval. Most of the finds came from the ice patch on the north side of the pass and only a few objects came from the south side. In the background can be recognized the Chilchli Glacier, which extends down from the summit of the Wildhorn $(3246 \mathrm{~m}$ asl).

\section{DISCOVERY, LOCATION, AND NATURAL ENVIRONMENT OF THE SCHNIDEJOCH SITE}

The Schnidejoch is a pass at an altitude of $2756 \mathrm{~m}$ asl in the Wildhorn region of the western Bernese Alps $\left(46^{\circ} 22^{\prime} 09.10^{\prime \prime} \mathrm{N}, 7^{\circ} 23^{\prime} 19.70^{\prime \prime}\right.$ E; Figs. 1, 2). Discovered in 2003 by hikers, the site has been the scene of intensive archaeological investigations since 2004 (Suter et al., 2005; Hafner, 2009). The catalyst for the discovery was the extremely warm summer of 2003, which led to a degree of glacial melt in the Alps that had not been experienced for a number of decades (Schär et al., 2004; Zemp et al., 2006). The small ice patch on the northern slope of the Schnidejoch was particularly affected by this melt and probably lost more than half of its volume during that summer. In the flat and slightly sloped depression, this loss was clearly visible as a marked decrease in the size of the ice surface.

This melting process continued in 2004 and 2005, so that one had to expect the entire ice patch to disappear completely (Fig. 3). The southern slope had been free from glaciations for quite some time. Most of the fragile objects made from organic materials were found along the receding edge of the ice within those two years. Contrary to all expectations, however, the summers in 2006-08 were no longer warm enough, and the residual ice remained stable during that time. The autumn of 2009 once again saw a considerably reduced mass of ice. But in 2010 and 2011, the ice stopped melting again, protected by a thick snow cover from winter precipitation. The ice mass at Schnidejoch is clearly too small to survive, but the experience of the last few years shows that we cannot predict how long it will take for the ice to disappear completely.

Geologically, the Wildhorn region and the Schnidejoch are part of the large formation of the Wildhorn nappe within the Helvetic nappes. The Schnidejoch area mainly consists of alpine hard limestone. All mountain slopes of this area are exposed to erosion, and massive accumulations of scree have formed at their bases. The geomorphology of the landscape at Schnidejoch is characterized by rugged rock faces, vast cones of debris, glacier forelands, moraines, and glaciers. The site is located in the subnival belt of the Alps, which ranges from the last continuous alpine meadows to the upper limits of flowering plants (Staffelbach, 2008). Present-day vegetation is limited to scattered cushion plants and mosses. The snow-free period in the area is limited to a few weeks between mid August and early October. At $2700 \mathrm{~m}$ asl in the Alps, one would generally expect continuous snow cover on more than 300 days a year and snowfall on 160 days a year, the summer months included (Ellenberg, 1996). The zone with the highest precipitation 

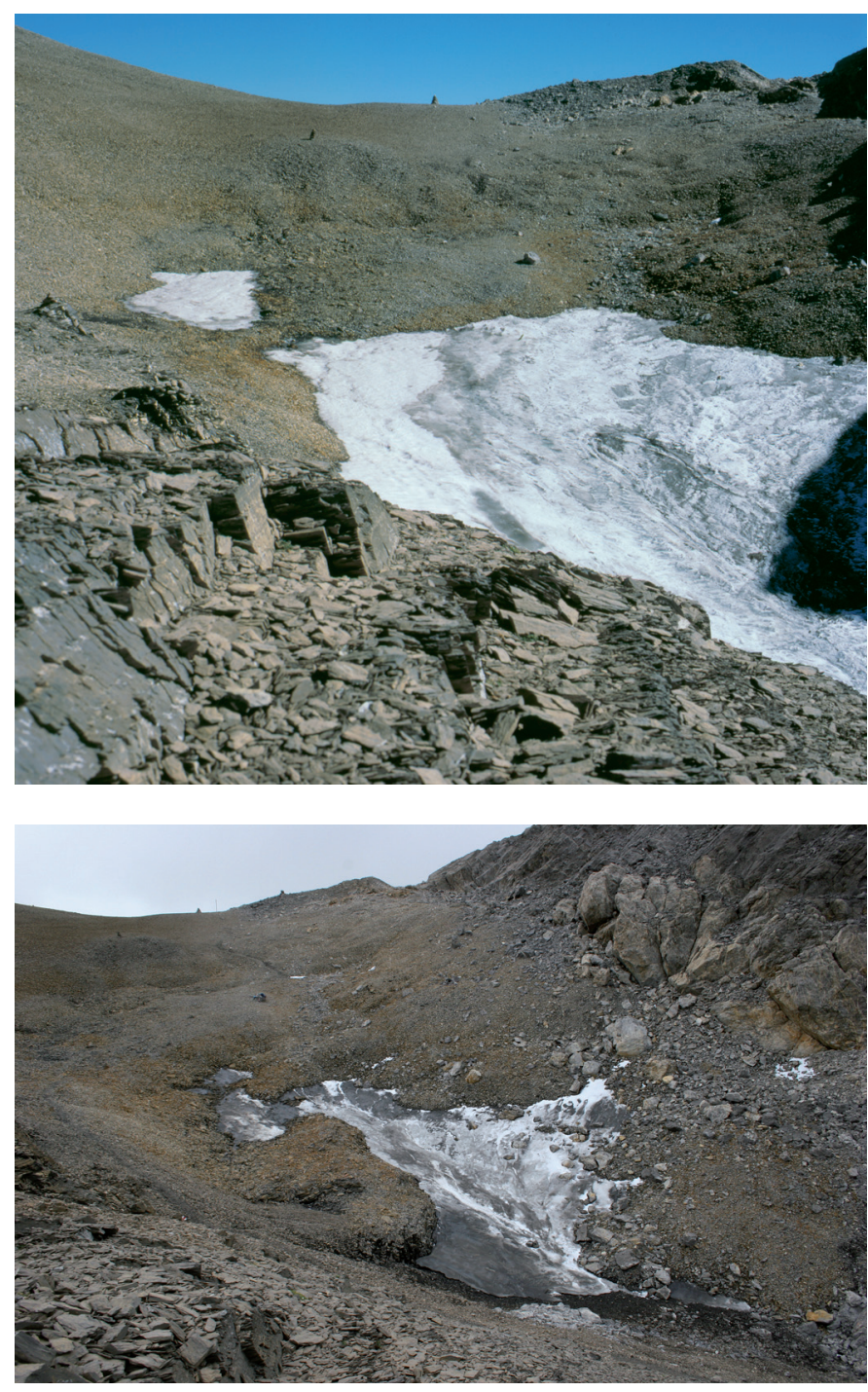

FIG. 3. Lenk, Schnidejoch. View of the site in September 2004 (above) and again in September 2009 (below). A dramatic melt has obviously occurred in the intervening five years.

in Switzerland extends along the northern alpine crest, reaching its maximum in the Bernese and Valais Alps. The annual average precipitation rates in the area of the Schnidejoch lie at more than $2000 \mathrm{~mm}$ (Schwarb et al., 2001).

\section{ARCHAEOLOGICAL INVESTIGATIONS AT SCHNIDEJOCH 2004-11}

More than 30 surveys were carried out by small teams between 2004 and 2011. Surveying usually begins when the pass area is free of snow - not before the end of Julyand ends with the first autumn snowfalls in October. At an altitude of almost $3000 \mathrm{~m}$ asl and because of an unfavourable seasonal decrease in solar radiation at the site, the ice would typically stop melting at the end of September. The archaeological work on the Schnidejoch does not consist of excavations in the proper sense, as most artifacts are found lying on the surface. In addition to scanning the terrain with the naked eye, the survey teams systematically searched the area surrounding the Schnidejoch with a metal detector. Except for a few finds from the beginning of the investigations, all finds were systematically mapped by means of a GPS station. Hobnails and wood with no sign of human alteration were mapped only by sector. More than 800 artifacts, most of organic material, were found between 2004 and 2011 on both sides of the summit of the pass. The preservation conditions for objects made of wood, bark, leather, and plant fibers were considerably better on the northern shady side than on the intensely sunlit southern side. A large majority of the finds, therefore, came from the northern side of the pass (Fig. 4). Organic finds have only a limited chance of being preserved once they are no longer encased in ice and become exposed to the elements. Once objects are free of the ice, they remain covered by snow for almost nine months of the year; for the remaining months, however, they are exposed to frequent rain and snowfall alternating with intense sunlight and strong winds. Artifacts lying on the surface are blown away by the wind or exposed to UV radiation, which makes them brittle. Compared to the lowlands, there are probably fewer active decomposers at $2700 \mathrm{~m}$ asl and at such low temperatures. Nevertheless, unprotected fragile artifacts such as leather or textiles would likely not have survived more than a few years. Timber fragments lying exposed on the surface of the scree would probably have survived considerably longer, perhaps for 50 to 100 years. Despite the fact that the deposition of the finds in the ice had occurred over several millennia, no stratigraphic sequence could be identified. Finds dating from quite different periods were intermingled. Moreover, the finds usually came from the base of the ice layer and were found lying on the bedrock. An explanation could be that darker objects, while still trapped in the ice, may absorb more energy than the lighter-coloured ice surrounding them and slowly melt their way to the bottom over time.

\section{Neolithic Finds}

The Neolithic finds from the Schnidejoch can be attributed to three time slots between 4800 and 2200 BC (Fig. 5). The chronological position of the Neolithic artifacts could be established only by means of radiocarbon dating, since neither pottery nor other typologically characteristic finds have so far been recovered. The dates of several objects point to the earliest phase being around 4800 to $4300 \mathrm{BC}$. The second Neolithic phase, from 3700 to $2900 \mathrm{BC}$, is currently represented by five $\mathrm{C}^{14}$ dates. A third period (2900 to $2200 \mathrm{BC}$ ) has been identified on the basis of 28 radiocarbon dates.

The oldest objects from the Schnidejoch include a fragment of a bowl made of elm wood (Fig. 6) and several fragments of arrows. Five pieces of leather and wood dating from around 800 to 1000 years later can be attributed to the second Neolithic time slot from 3700 to 2900 BC. The third Neolithic time slot, between 2900 and 2200 BC, 


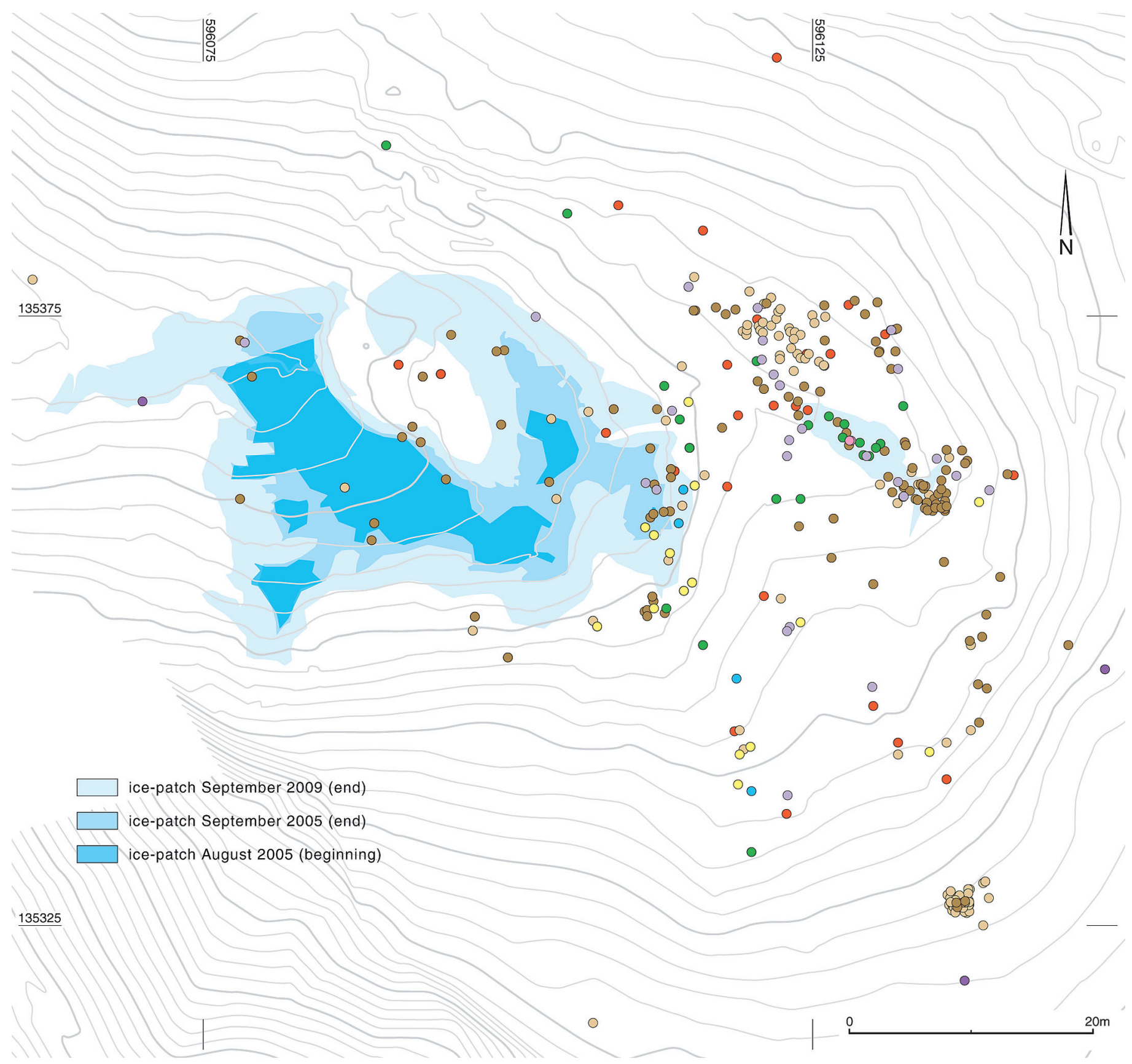

FIG. 4. Lenk, Schnidejoch. Northern side of the pass. Extension and reduction of the ice patch between 2005 and 2009 and distribution of the finds.

yielded particularly numerous and spectacular finds. An almost complete bow kit was found over the course of a few years in many pieces that were likely from one kit. The bow kit consisted of a complete bow, $1.6 \mathrm{~m}$ long, made of yew wood (Fig. 7); a bow string made of an unidentified material, probably of animal origin; a bow case made of birch bark (Fig. 8); numerous complete arrow shafts, as well as many fragmented ones (Fig. 9); and two arrowheads. This Neolithic equipment was supplemented by a leather legging (Fig. 10). This item of clothing exhibited obvious seams stitched with plant fibers and repairs in the form of patches. This large piece of leather measuring $89 \mathrm{~cm} \times$ $60 \mathrm{~cm}$ - probably one of the largest preserved prehistoric leather fragments ever found - was analyzed using various methods. This analysis was possible because from the outset the conservators had chosen not to use chemicals to conserve the leather fragments. To this day, the leather objects have remained untreated and are stored in stable and dry conditions. The mitochondrial DNA analyses carried out by Angela Schlumbaum from the University of Basel revealed that the leather had come from a domesticated goat and that the animal belonged to a genetic group that is no longer present in Europe today, but still exists in Southeast Asia. This archaeogenetic result has far-reaching consequences for our understanding of the domestication of goats (Schlumbaum et al., 2010). Several leather samples were analyzed by Jorge 


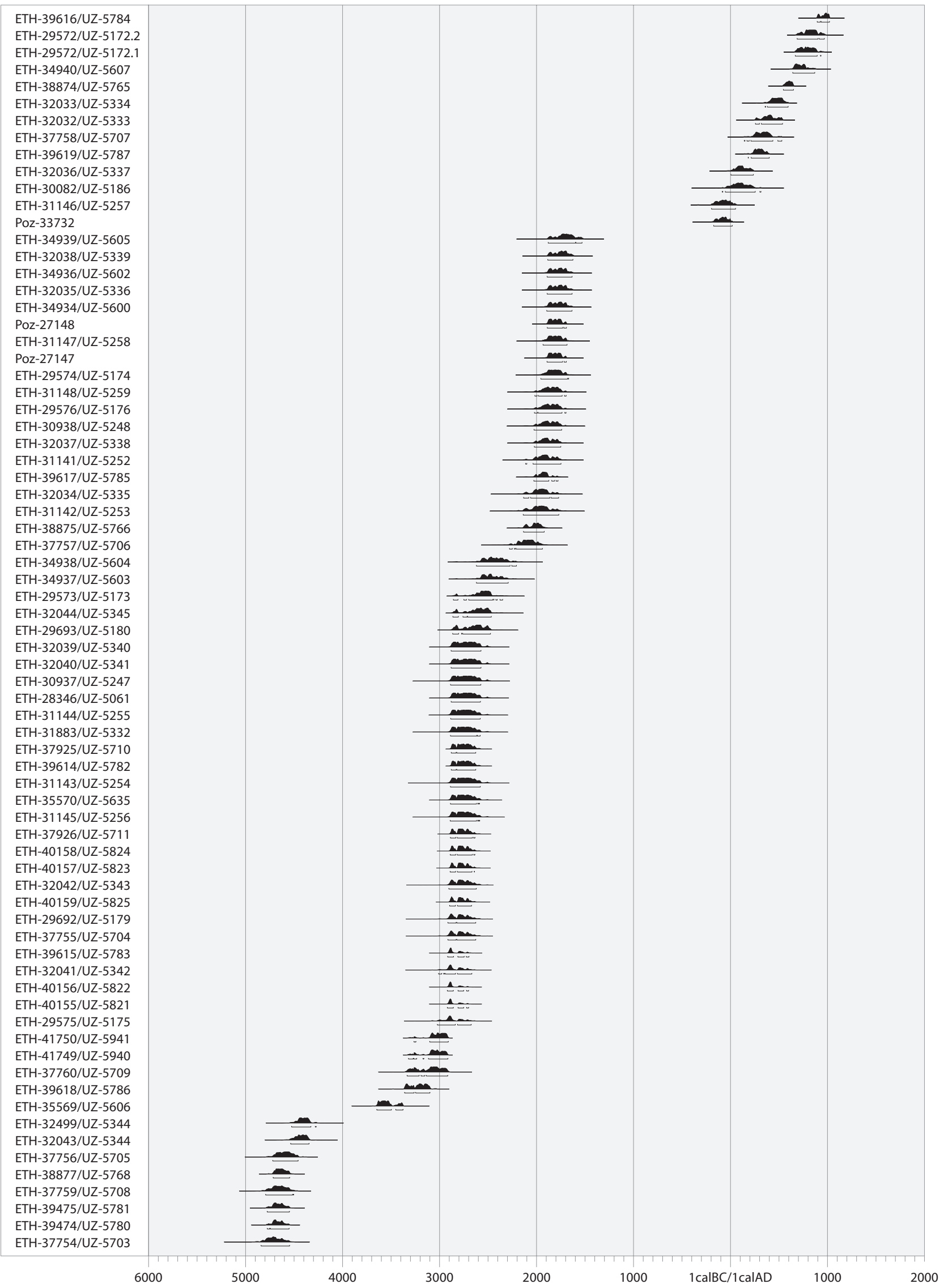

FIG. 5. Schnidejoch. Calibrated radiocarbon dates. Calibration was done with OxCAL 4.1 using the IntCal 09 curve of the programme (Bronk Ramsey, 2009). 

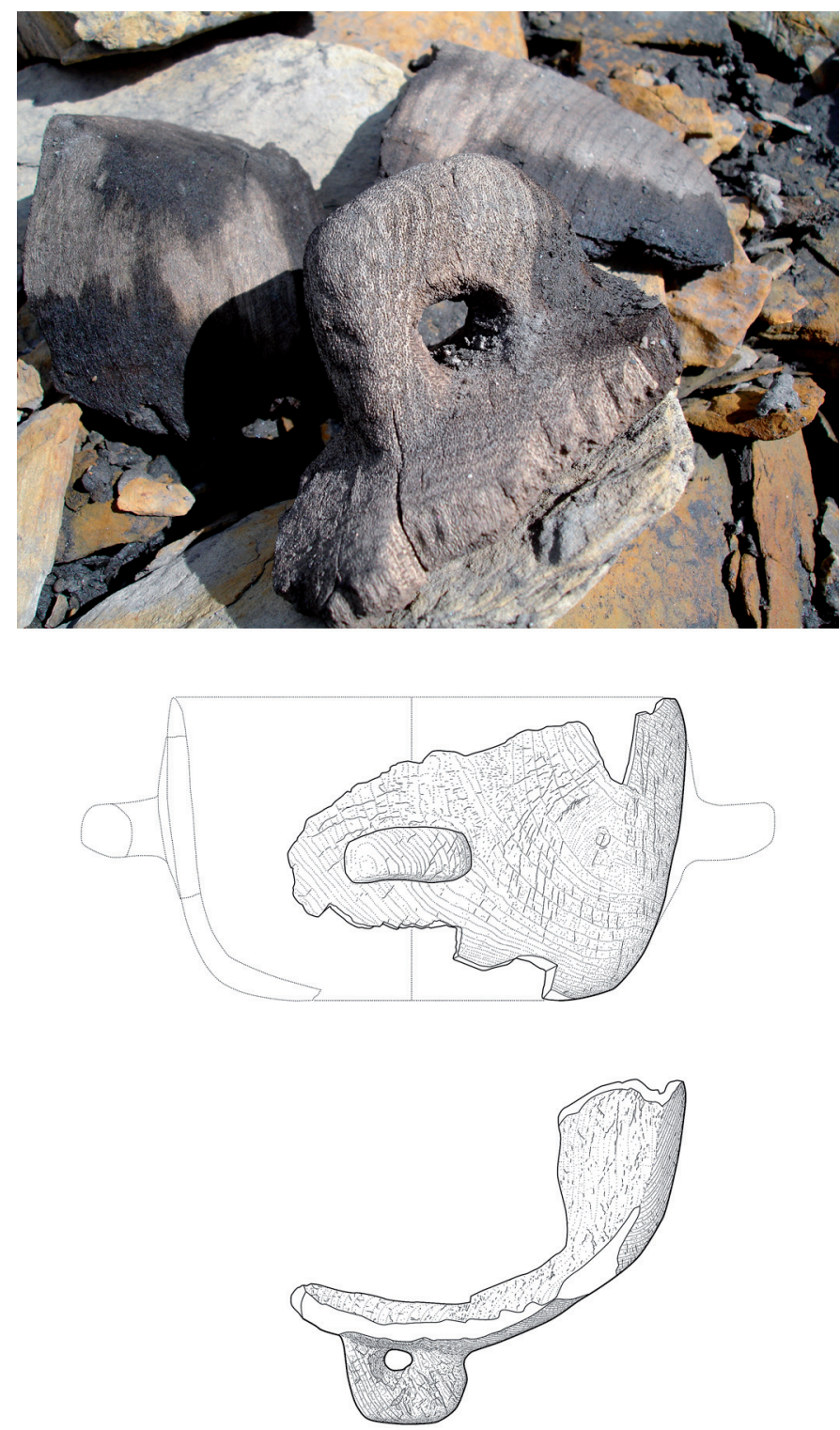

FIG. 6. Lenk, Schnidejoch. Fragment of a Neolithic wooden bowl, dated $4500-4300 \mathrm{BC}$ and made from elm wood. The complete diameter of the bowl is $19 \mathrm{~cm}$.

Spangenberg from the University of Lausanne using molecular and isotope chemistry $\left(\delta^{13} \mathrm{C}\right.$ and $\delta^{15} \mathrm{~N}$ of the leather as a whole and sample-specific $\delta^{13} \mathrm{C}$ analyses of the fatty acids extracted using organic solvents). These analyses revealed that the various archaeological leather samples contained a mixture of endogenous animal lipids and exogenous plant lipids (Spangenberg et al., 2010). Considerable amounts of waxes and phytosterols found in all the samples, as well as numerous biomarkers of coniferous wood species identified in the Schnidejoch leather samples, show that the wearers of these items of clothing had often frequented subalpine coniferous woodlands and that watery extracts of various plants had been used as tanning agents. This finding has provided proof for the first time that plant tanning agents were already known and used in the Neolithic period. This means that complex tanning techniques, previously thought

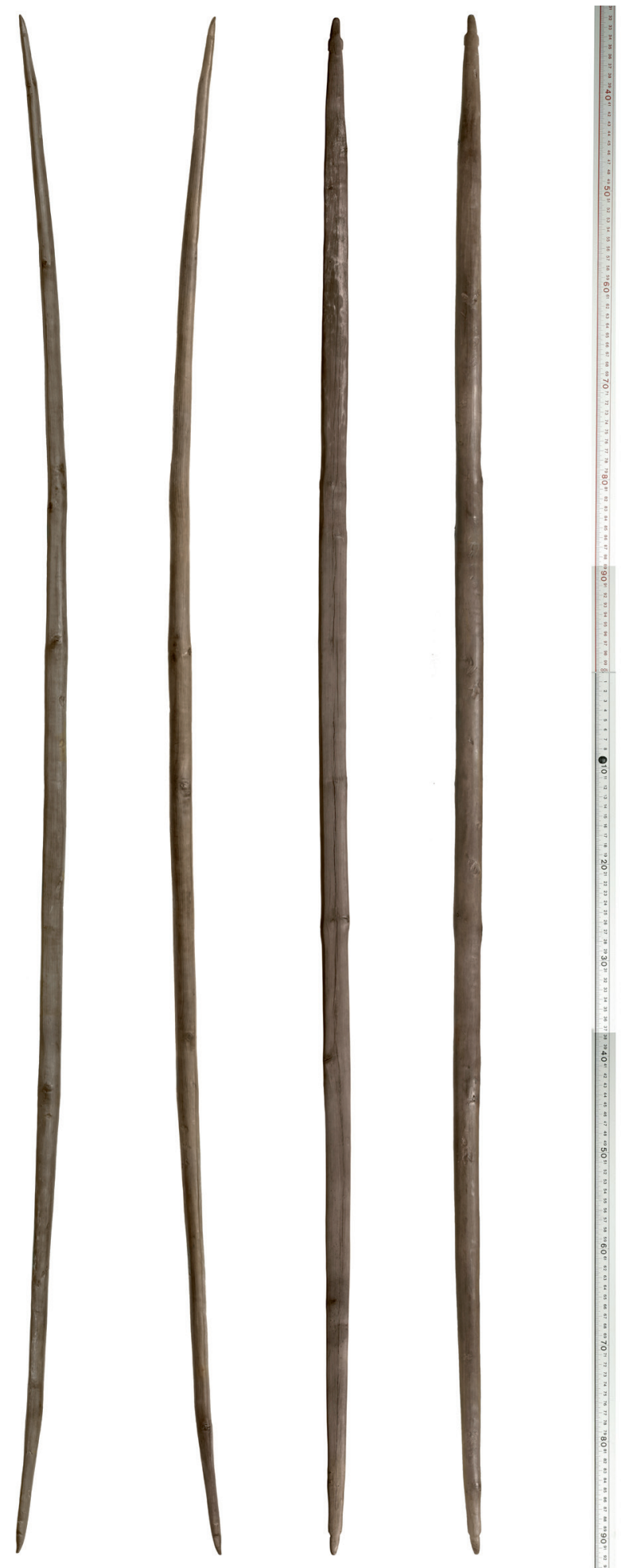

FIG. 7. Lenk, Schnidejoch. The Neolithic bow made of yew wood and dating $2900-2700$ BC was found in 2003 by hikers. The total length of the bow is $162 \mathrm{~cm}$.

to have been unknown until later periods, were already being used (S. Volken, pers. comm. 2010).

Added together, various artifacts from the third Neolithic time slot (2900 to $2200 \mathrm{BC}$ ) would make up a large part of the equipment of an armed man who was moving 


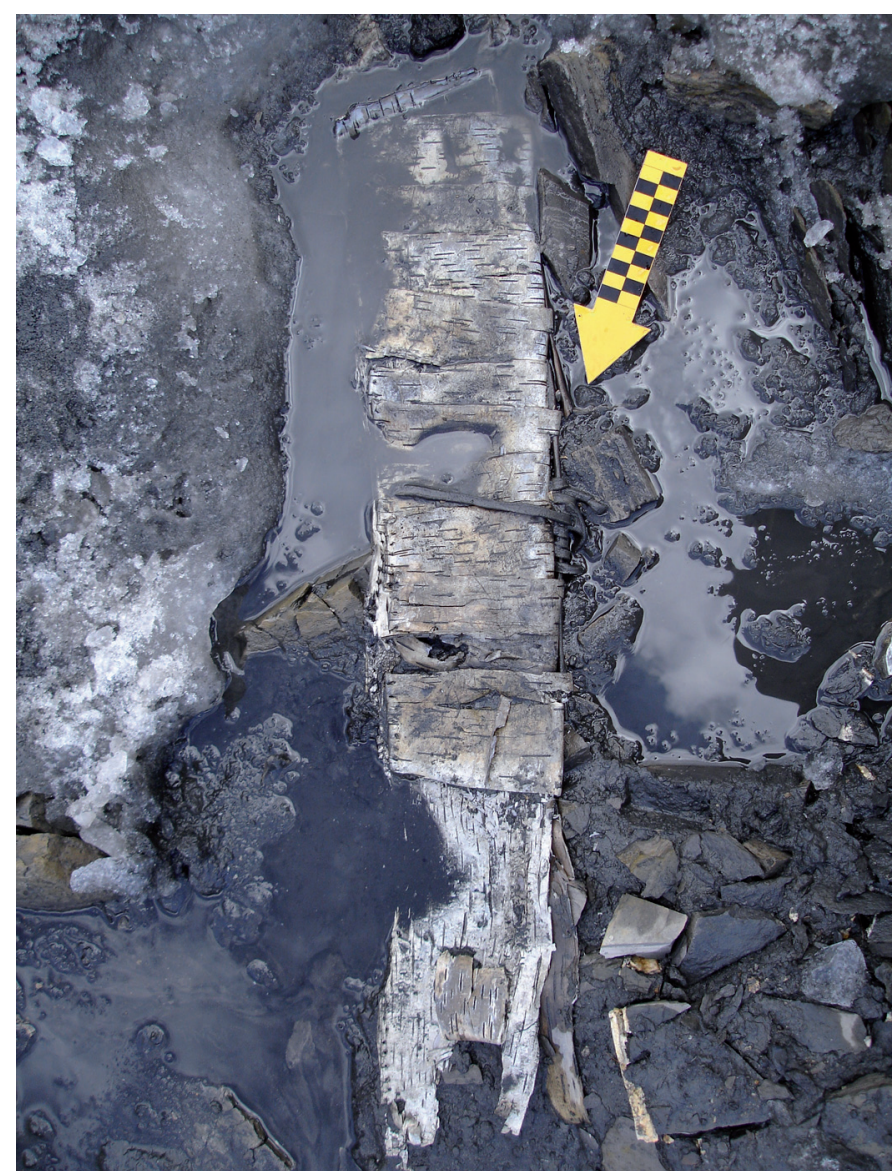

FIG. 8. Lenk, Schnidejoch. Middle section of a Neolithic bow case made of birch bark and reinforced with pieces of wood and strips of leather, $2900-2700 \mathrm{BC}$.

across the high mountain ranges. There are striking similarities between the Schnidejoch kit and the equipment that belonged to the frozen body from the Tisenjoch. It is highly unlikely that both these items of clothing, which would have been necessary for survival in the mountains, and also the weapons, which must have been at least as important,

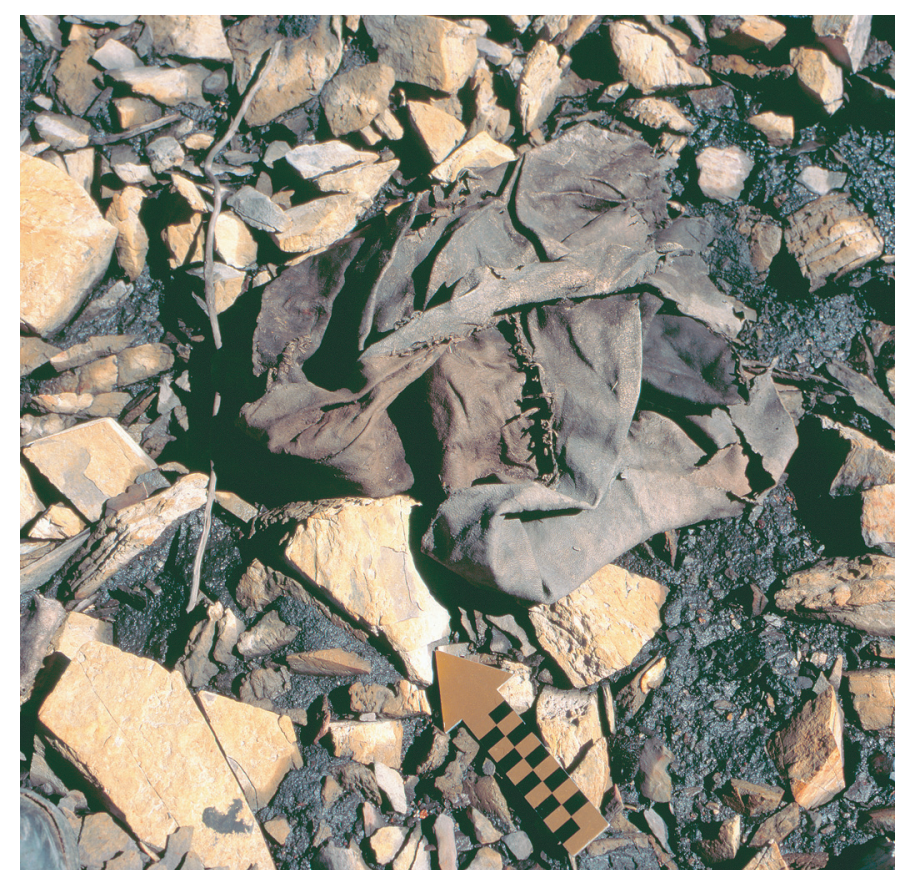

FIG. 10. Lenk, Schnidejoch. A Neolithic leather legging, 2900-2700 BC, in the context where it was found.

were simply lost. This partial assemblage in a sense mirrors the situation on the Tisenjoch, where, as is generally known, a person had come to a violent end (Egg and Spindler 2009:199-209). One may assume that the Schnidejoch finds also represent a casualty. However, it was not necessarily a murder or manslaughter: it might also have been an unfortunate accident.

\section{Early Bronze Age Finds}

Nineteen objects have been radiocarbon-dated to ca. 2200 to 1500 BC, a period that covers the Early Bronze Age (Fig. 5). Surprisingly, there is a lack of Middle and Late Bronze Age dates. Since glaciers retreated several times 


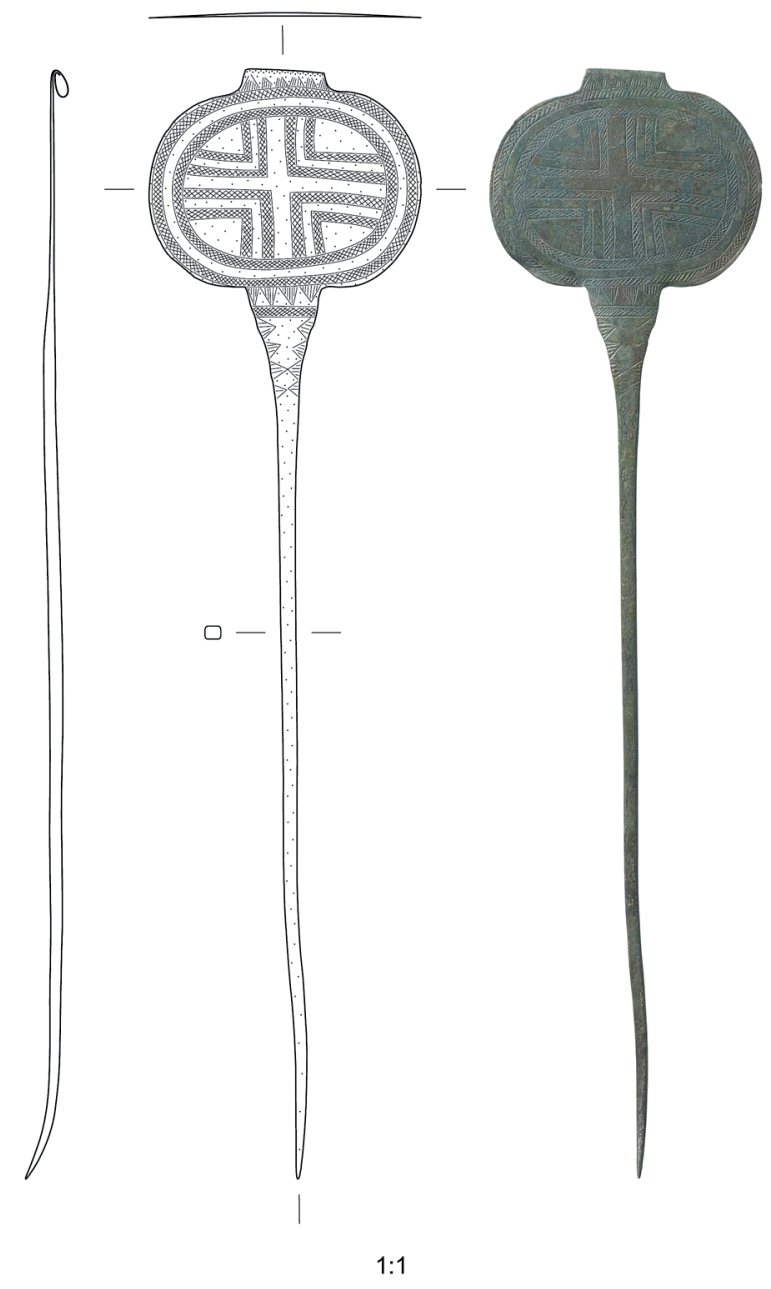

FIG. 11. Lenk, Schnidejoch. Disc-headed pin from the Early Bronze Age, dating from 1800-1600 BC.

during this time span, one would expect to find Late Bronze Age radiocarbon dates in particular. But as yet, there is a gap of 1500 years between the latest dates of the Early Bronze Age "time slot" and the earliest Iron Age radiocarbon dates.

Besides a typologically distinct bronze pin, the Early Bronze Age objects from the Schnidejoch again consist mainly of artifacts made of organic materials. The bronze pin is a richly decorated, disc-headed pin, which is $22.7 \mathrm{~cm}$ long (Fig. 11). The decoration on the disc consists of two concentric circles enclosing a central cross made up of eight chevrons. The head of the pin is rolled into a loop, which served to secure the pin by means of a piece of string. Both the loop and the shaft of the pin are decorated with filled triangles. Similar pins were found in burial sites near Conthey and Ayent in the Rhône Valley below Schnidejoch (Hafner, 1995:151 -152, 202; David-Elbiali, 2000:394, 412). All the discoveries of disc-headed pins in Switzerland have so far been made in the Rhône Valley. It is not clear whether the Schnidejoch pin was lost or deliberately deposited at the site. Since this type of pin has a loop with which to secure it, one must consider the possibility that it was left there as an offering.
Other finds of particular interest were various fragments of a wooden vessel, of which only the base was completely preserved (Fig. 12). The base and the body of the vessel, fragments of which were also found, were sewn together by thin twigs. Other Early Bronze Age finds consisted of leather artifacts and rings made from plaited twigs.

\section{Iron Age, Roman and Medieval Finds}

The latest objects found on the Schnidejoch date from a period which, because of the relative inaccuracy of the radiocarbon dates, covers not only the Iron Age, but also the Roman and medieval periods. The actual dates represent the time span between about 200 BC and AD 1000 (Fig. 5). The finds recovered from the pass include various Roman metal artifacts: a brooch (Fig. 13), a coin, and more than 150 hobnails. Besides the coin from the pass itself, two other coins were found just below it. One of these was discovered at Lake Iffig, where fragments of Roman tiles, which suggest the presence of some kind of hostel, have been found on several occasions (Grütter, 1985). Another coin was found in the area of the Wildhorn hut in the 1940s, but has since been lost (Hafner, 2008). Other finds included leather fragments, remnants of shoes, and a small number of textiles.

\section{CONCLUSIONS}

It is not possible to identify the exact routes that were chosen in each period to cross the Schnidejoch. The fact remains, however, that the pass was relatively easy and safe to traverse from both sides. Because of the topographical situation, only a few clearly defined routes were possible. The southern access was always easier because ice cover on the slopes with south exposure was minor. Access from the north was also easy at times when the neighbouring Chilchli Glacier had retreated to a large extent, as is currently the case. At the height of the Little Ice Age, around 1850, the glacier extended about $1200 \mathrm{~m}$ farther than it does today. The glacier then clearly reached farther north and was sliding down the valley over a steep drop (Fig. 14). Because of glacier mechanics, a tensile zone with deep cracks and crevasses was then formed in the area of the present-day path. In such periods of advancing glaciers, the route could have been accomplished only by experienced climbers. The dangers posed by crevasses and icefall rendered this area of the glacier a dangerous terrain and required appropriate safety measures. In these conditions, the key location on the northern access route was not situated at the highest point of the route, but almost an hour's hike below it. The chronological distribution of archaeological material from Schnidejoch shows a correlation between the periods represented by archaeological finds and the periods during which the glaciers in the alpine region were retreating. Crossing the pass safely was probably possible only at times when the climate was warmer and the glaciers had greatly 


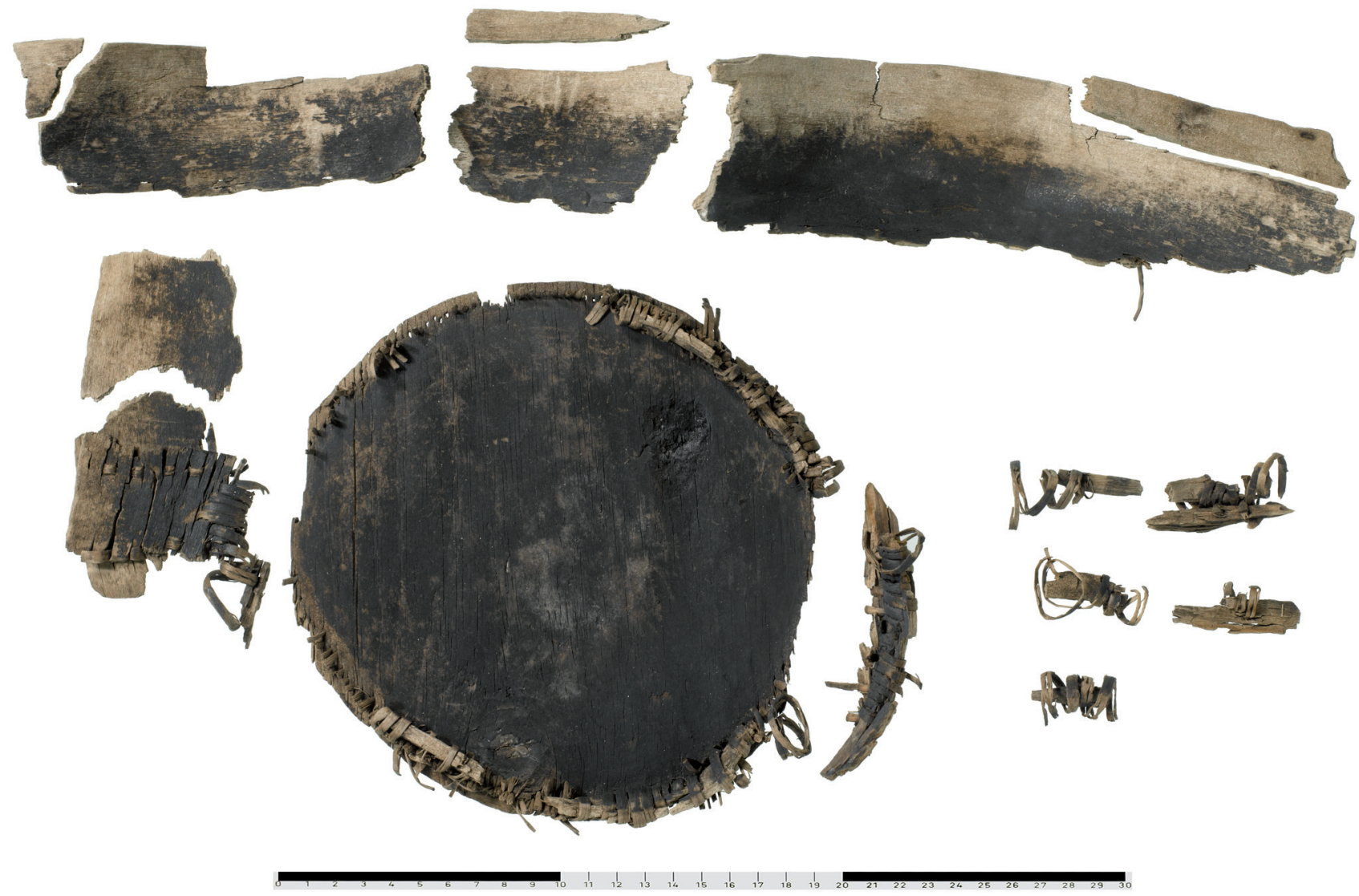

FIG. 12. Lenk, Schnidejoch. Early Bronze Age wooden vessel, consisting of a base with remnants of the seam and body fragments. Radiocarbon dating gives an age of $1800-1600 \mathrm{BC}$. The object is made from various species of wood.

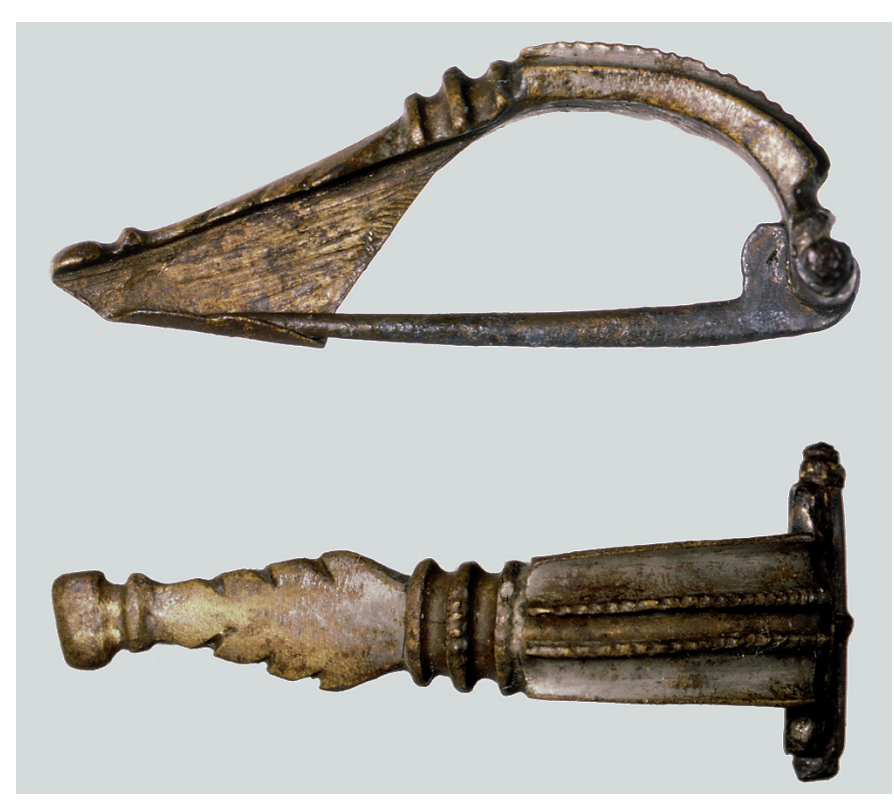

FIG. 13. Lenk, Schnidejoch. Roman hinge fibula, dating from the 1st century AD. The fibula is made out of tin-coated bronze (length: $3.9 \mathrm{~cm}$ ).

retreated. One can postulate a direct link between retreating glaciers and the use of the Schnidejoch pass (Grosjean et al., 2007; Nussbaumer et al., 2011). In general, one may assume that in prehistoric and early historic times, alpine passes that were considered safer and easier to cross were generally preferred. The distances and altitudes that had to be negotiated were probably only of secondary importance.

Hunting would probably have been one of the main incentives to advance into the rocky and glaciated areas of the High Alps. The inhabitants of the alpine zones always relied on visiting different locations depending on the season-at least with regard to animal herding. It is unlikely that the Schnidejoch was crossed with cattle: various short steep inclines in the terrain on both sides of the pass made the paths too arduous, and certain locations would even have been completely impassable. Sheep and goats, on the other hand, would have encountered no difficulties in crossing the Schnidejoch. Neolithic farming communities, documented through settlements and burial sites, are located south of Schnidejoch in the Rhône Valley, but no Neolithic settlements have been found in the northern valleys. Most probably the Schnidejoch pass was used by early farming communities from the south side in search of hunting areas and herding places on the north side of the pass. The finds recovered from the Schnidejoch suggest that high-altitude passes in the Alps were already used in the 5th millennium BC. Further radiocarbon-dated objects reveal that the region around Schnidejoch attracted individuals throughout the Neolithic and the Early Bronze Age (4800-1600 BC). The crossing of passes in the Alps was a basic prerequisite 

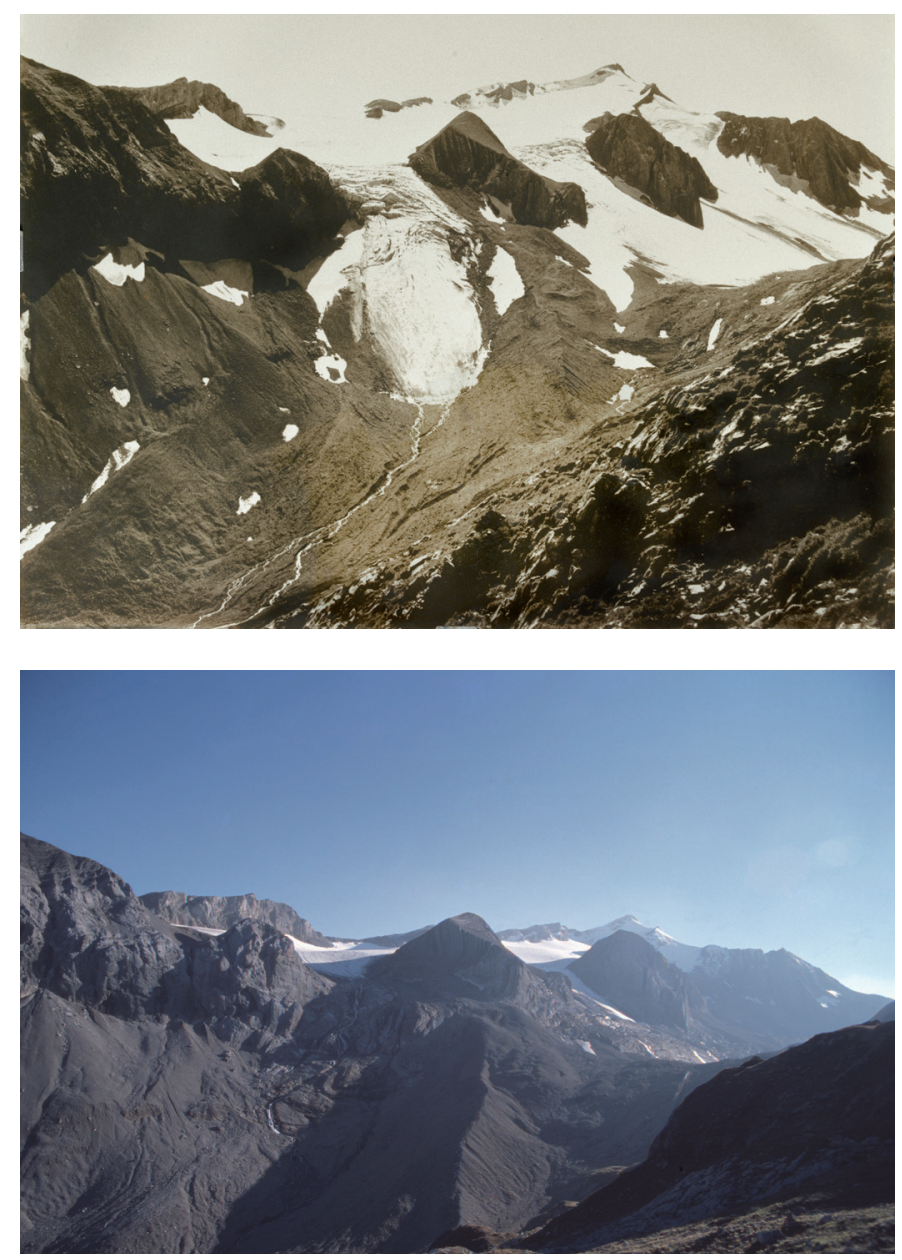

FIG. 14. Lenk, Schnidejoch and Chilchli Glacier. The pictures show the key location on the way to the Schnidejoch from the north. The top photograph, taken c. 1900-1920, shows an area of crevasses between the two triangular rock faces in the centre of the photograph that can be scaled only using mountaineering equipment. However, the bottom photo, taken in 2008, shows that at the present state of glaciation, the way to the Schnidejoch is simple and risk-free.

for the formation of trade networks and for general communication between different valleys. This situation can be assumed starting from the Early Bronze Age, for which an intensive exchange system is confirmed in the archaeological record through similar burial rites and grave goods. In Roman times, the Schnidejoch was not among the crossings known from written sources. However, one may assume that only the great long-distance routes were mentioned in the geographic accounts. The hypothesis of a Roman hostel at Lake Iffig, at the northern access, confirms the importance of Schnidejoch as a connecting route between alpine valleys (Grütter, 1985; Hafner, 2008). The most recent historically interesting finds from the Schnidejoch date from the 10th century. These medieval artifacts likely represent the final phase in the use of the pass, which probably became difficult and unsafe to cross with the onset of the Little Ice Age and the associated glacier advance from 1300 onwards. There are no more traces of later crossings of the pass until the 20th century: modern lost objects bear witness to the activities of mountaineers and ski-tourists, as well as military exercises that have taken place in the area around the summit of the pass.

\section{ACKNOWLEDGEMENTS}

The author thanks Sandy Hämmerle, Galway, Ireland, for the translation, and three anonymous reviewers for their valuable comments on an earlier draft.

\section{REFERENCES}

Andrews, T.D., MacKay, G., and Andrew, L. 2009. Hunters of the alpine ice: The NWT Ice Patch Study. Yellowknife: Prince of Wales Northern Heritage Centre.

Astveit, L.I. 2007. Hoyfjellsarkeologi under sno og is: Global oppvarming, fonnjakt og funn fra snfonner datert till steinalder. Viking 2007:7-22.

Bazzanella, M., Dal Rì, L., Maspero, A., and Tomedi, I. 2005. Iron Age textile artefacts from Riesenferner/Vedretta di Ries (Bolzano/Bozen - Italy). In: Bichler, P., Grömer, K., Hofmann-de Keijzer, R., Kern, A., and Reschreiter, H., eds. Hallstatt textiles: Technical analysis, scientific investigation and experiment on Iron Age textiles. Oxford BAR International Series 1351. $151-160$.

Bellwald, W. 1992. Drei spätneolithisch/frühbronzezeitliche Pfeilbogen aus dem Gletschereis am Lötschenpass. Archäologie der Schweiz 15:166-171.

Bortenschlager, S., and Oeggl, K. 2000. The Iceman and his natural environment: Palaeobotanical results. Wien and New York: Springer-Verlag. $166 \mathrm{p}$.

Bronk Ramsey, C. 2009. Bayesian analysis of radiocarbon dates. Radiocarbon 51(1):337-360.

Cornioley, R. 2006. Der Flugzeugabsturz einer amerikanischen Dakota auf dem Gauligletscher im November 1946. Vor 60 Jahren war das Haslital Schauplatz der grössten alpinen Rettungsaktion. Berner Zeitschrift für Geschichte 2006/3:115-155.

dal Rì, L. 1996. I ritrovamenti presso il refugio Vedretta di Ries/Rieserferner nelle Alpe Aurine $/ 2850$ m s.l.m.). Notizia preliminare. Rivista di Scienze prehistoriche 47:367-396.

David-Elbiali, M. 2000. La Suisse occidentale au IIe millénaire av. J.-C. Chronologie, culture, intégration européenne. Lausanne: Cahiers d'archéologie romande.

Dixon, J.E., Manley, W.F., and Lee, C.M. 2005. The emerging archaeology of glaciers and ice patches: Examples from Alaska's Wrangell-St. Elias National Park and Preserve. American Antiquity 70(1):129-143.

Egg, M., and Spindler, K. 2009. Kleidung und Ausrüstung der kupferzeitlichen Gletschermumie aus den Ötztaler Alpen. Der Mann im Eis 6. Mainz: Verlag des Römisch-Germanischen Zentralmuseums.

Ellenberg, H. 1996. Vegetation Mitteleuropas mit den Alpen in ökologischer, dynamischer und historischer Sicht. 5, ed. Stuttgart. 
Farbregd, O. 1972. Pilefunn frå Oppdalsfjella [Arrow finds from the Oppdal Mountains]. Det Kgl. Norske Videnskabers Selskab, Museet, Miscellanea 5. Trondheim, Norway. 105 117. Summary in English (105-109).

2009. Archery history from ancient snow and ice. In:

Brattli, T., ed. The $58^{\text {th }}$ International Sachsensymposium, 1-5 September 2007. Vitark 7, Acta Archaeologica Nidrosiensia. Trondheim, Norway: Tapir Akademisk Forlag. 157-170.

Farnell, R., Hare, P.G., Blake, E., Bowyer, V., Schweger, C., Greer, S., and Gotthardt, R., 2004. Multidisciplinary investigations of alpine ice patches in southwest Yukon, Canada: Paleoenvironmental and paleobiological investigations. Arctic 57(3):247-259.

Finstad, E., and Pilø, L. 2010. Kulturminner og løsfunn ved isbreer og snøfonner i høyfjellet [Cultural heritage and stray finds on glaciers and snow patches in the mountains]. Kulturhistoriske Skrifter Nr. 1. Lillehammer: Oppland Fylkskommune.

Grosjean, M., Suter, P.J., Trachsel, M., and Wanner, H. 2007. Ice-borne prehistoric finds in the Swiss Alps reflect Holocene glacier fluctuations. Journal of Quaternary Science 22(3):203-207.

Grütter, H. 1985. Der Rawilpass - mit antikem Vorgänger am Kaltwasserpass (Col des Eaux Froides)? Zum Fund römischer Leisten- und Rundziegelfragmente am Westufer des Iffigsees (2065 müM). Jahrbuch der Geographischen Gesellschaft Bern $55: 453-466$

Hafner, A. 1995. Die Frühe Bronzezeit in der Westschweiz. Funde und Befunde aus Siedlungen, Gräbern und Horten der entwickelten Frühbronzezeit. Bern: Staatlicher Lehrmittelverlag.

- 2008. Schnidejoch et Lötschenpass: trouvailles romaines sur deux cols des Alpes bernoises occidentales. In: Appolonia, L., Wiblé, F., and Framarin, P., eds. Alpis Poenina/Grand SaintBernard. Une voie à travers l'Europe. Séminaire de clôture, 11-12 April, Fort de Bard (Vallée d'Aoste). 477-485.

. 2009. Geschichte aus dem Eis - Archäologische Funde aus alpinen Gletschern und Eismulden. Mitteilungen der Naturforschenden Gesellschaft in Bern 66:159-171.

Hare, P.G., Greer, S., Gotthardt, R., Farnell, R., Bowyer, V., Schweger, C., and Strand, D. 2004. Ethnographic and archaeological investigations of alpine ice patches in southwest Yukon, Canada. Arctic 57(3):260-272.

Höpfel, F., Platzer, W., and Spindler, K. 1992. Der Mann im Eis. Bericht über das Internationale Symposium 1992 in Innsbruck. Innsbruck: Eigenverlag der Uni Innsbruck. 464 p.

Lee, C.M. 2010. Global warming reveals wooden artefact frozen over 10000 years ago in the Rocky Mountains. Antiquity 84(325). www.antiquity.ac.uk/projgall/lee325.

Martinelli, V. 1996-2002. Guerra Alpina sull' Adamello, Vol. I-III. Bolzano/Pinzolo.

Meyer, W. 1992. Der Söldner vom Theodulpass und andere Gletscherfunde aus der Schweiz. In: Höpfel, F., Platzer, W., and Spindler, K., eds. Der Mann im Eis. Bericht über das Internationale Symposium 1992 in Innsbruck. Innsbruck: Eigenverlag der Uni Innsbruck. 321-333.

Nussbaumer, S., Steinhilber, F., Trachsel, M., Breitenmoser, P., Beer, J., Blass, A., Grosjean, M., Hafner, A., Holzhauser, H.,
Wanner, H., and Zumbühl, H. 2011. Alpine climate during the Holocene: A comparison between records of glaciers, lake sediments and solar activity. Journal of Quaternary Science 26(7):703-713, doi:10.1002/jqs. 1495.

Rageth, J. 1995. Ein Gletscherleichenfund im Piz Kesch-Gebiet. Bündner Monatsblatt 5:365-391.

Rasper, M. 2011. Das Eis geht. Die Vergangenheit kommt. P.M. Magazin 6:78-83.

Schär, C., Vidale, P.L., Lüthi, D., Frei, C., Häberli, C., Liniger, M.A., and Appenzeller, C. 2004. The role of increasing temperature variability in European summer heatwaves. Nature 427:332-336.

Schlumbaum, A., Campos, P.F., Volken, S., Volken, M., Hafner, A., and Schibler, J. 2010. Ancient DNA, a Neolithic legging from the Swiss Alps and the early history of goat. Journal of Archaeological Science 37(6):1247-1251.

Schwarb, M., Daly, C., Frei, C., and Schär, C. 2001. Mittlere jährliche Niederschlagshöhen im europäischen Alpenraum 1971-1990. Hydrologischer Atlas der Schweiz. Tafel 2.6. Bern.

Spangenberg, J.E., Ferrer, M., Tschudin, P., Volken, M., and Hafner, A. 2010. Microstructural, chemical and isotopic evidence for the origin of Late Neolithic leather recovered from an ice field in the Swiss Alps. Journal of Archaeological Science 37(8):1851-1865.

Spindler, K., Rastbichler-Zissernig, E., Wilfing, H., zur Nedden, D., and Nothdurfter, H. 1995. Neue Funde und Ergebnisse. Der Mann im Eis/The man in the Ice 2. Mainz: Verlag des Römisch-Germanischen Zentralmuseums. 320 p.

Spindler, K., Wilfing, H., Rastbichler-Zissernig, E., zur Nedden, D., and Nothdurfter, H., eds. 1996. Human mummies: A global survey of their status and the techniques of conservation. The Man in the Ice 3. Wein: Springer-Verlag. 294 p.

Stadler, H. 2005. Untertan kontra Obrigkeit. Die Gletscherleiche des Wilderers Norbert Mattersberger vom Gradetzkees in Osttirol. In: Holzner, J., and Walde, E., eds. Brüche und Brücken. Kulturtransfer im Alpenraum von der Steinzeit bis zur Gegenwart. Bozen. 236-249.

Staffelbach, H. 2008. Handbuch Schweizer Alpen. Pflanzen, Tiere, Gesteine und Wetter. Der Naturführer. Bern.

Suter, P.J., Hafner, A., and Glauser, K. 2005. Lenk - Schnidejoch. Funde aus dem Eis-ein vor- und frühgeschichtlicher Passübergang. Archäologie im Kanton Bern 6B:499-522.

VanderHoek, R., Tedor, R.M., and McMahan, J.D. $2007 \mathrm{a}$. Cultural materials recovered from ice patches in the Denali Highway region, central Alaska, 2003-2005. Alaska Journal of Anthropology 5(2):185-200.

VanderHoek, R., Wygal, B., Tedor, R.M., and Holmes, C.E. 2007b. Survey and monitoring of ice patches in the Denali Highway region, central Alaska, 2003-2005. Alaska Journal of Anthropology 5:67-86.

Von Schulz, M. 2003. Hoffen auf Hannibal. Der Spiegel 37. www. spiegel.de/spiegel/print/d-28530373.html.

Wyss, R. 1971. Die Eroberung der Alpen durch den Bronzezeitmenschen. Zeitschrift für schweizerische Archäologie und Kunstgeschichte 28:130-145. 


\section{$202 \cdot$ A. HAFNER}

. 1991. Die frühe Besiedlung der Alpen aus archäologischer Sicht. In: Aerni, K., Egli, H.-R., and Fehn, K., eds. Siedlungsprozesse an der Höhengrenze der Ökumene am Beispiel der Alpen. Bern/Bonn. 67-86.
Zemp, M., Häberli, C., Hoelzle, M., and Paul, F. 2006. Alpine glaciers to disappear within decades? Geophysical Research Letters 33, L13504, doi:10.1029/2006GL026319. 